Sitasi artikel ini (APA $6^{\text {th }}$ Edition style):

Adewiyah, R. (2018). Upaya Peningkatan Hasil Belajar Siswa dengan Menggunakan Metode Team Games Tournament (TGT) pada Kompetensi Dasar Sumber Daya Alam dan Kegiatan Ekonomi Masyarakat di Kelas V SD Negeri 060924. MUKADIMAH, 2(2), 1-10.

\title{
UPAYA PENINGKATAN HASIL BELAJAR SISWA DENGAN MENGGUNAKAN METODE TEAM GAMES TOURNAMENT (TGT) PADA KOMPETENSI DASAR SUMBER DAYA ALAM DAN KEGIATAN EKONOMI MASYARAKAT DI KELAS V SD NEGERI 060924 MEDAN AMPLAS
}

\author{
Rabiatul Adewiyah \\ Guru SD Negeri 060924 Medan Amplas \\ rab.adewiyah@gmail.com
}

\begin{abstract}
ABSTRAK
Penelitian ini bertujuan untuk meningkatkan hasil belajar siswa pada kompetensi dasar sumber daya alam dan kegiatan ekonomi masyarakat di kelas V SD Negeri 060924 Medan Amplas melalui penerapan metode team games tournament (TGT). Jenis penelitian yang dilakukan dalam penelitian ini adalah Penelitian Tindakan Kelas (PTK), penelitian ini dilakukan dalam dua siklus yang didalamnya terdapat empat tahapan utama, yaitu perencanaan, tindakan, pengamatan, dan refleksi. Berdasarkan analisis data yang telah dilakukan peneliti dalam penelitian ini, maka dapat ditarik kesimpulan sebagai berikut: 1) Penggunaan metode pembelajaran Team Games Tournament (TGT) pada mata pelajaran IPS pokok bahasan sumber daya alam dan kegiatan ekonomi masyarakat dapat meningkatkan hasil belajar siswa; 2) Dari pelaksanaan siklus I nilai rata-rata yang diperoleh siswa adalah 5,47 dan siswa yang tuntas adalah sebanyak 10 siswa atau 33,33\%; dan 3) Hasil pelaksanaan siklus II nilai rata-rata yang diperoleh siswa adalah 7,25 dan jumlah siswa yang tuntas sebanyak 23 siswa atau 76,67\%.
\end{abstract}

Kata Kunci: Hasil Belajar, Metode Team Games Tournament.

\section{PENDAHULUAN}

Pendidikan merupakan salah satu usaha yang bertujuan mencerdaskan kehidupan bangsa, dan sebagai kunci pokok untuk mencapai cita-cita suatu bangsa. Yang mana untuk mewujudkan cita-cita tersebut perlu dilakukan usaha yang semaksimal mungkin dari guru, guru harus mampu dalam mengelola komponen pembelajaran dan kreatif dalam mengembangkan materi pelajaran sehingga materi pelajaran tersebut dapat diserap oleh peserta didik sehingga tujuan pengajaran dapat tercapai. 
Pada saat pembelajaran di sekolah, terdapat banyak unsur yang berkaitan dan menentukan keberhasilan dalam proses belajar mengajar. Unsur-unsur tersebut adalah: pendidik (guru), peserta didik (siswa), kurikulum pengajaran, tes, dan lingkungan. Siswa sebagai subjek dalam proses tersebut juga sangat berperan dalam keberhasilan belajar mengajar (Sudjana, 2001:2). IPS adalah bidang studi yang mempelajari, menelaah, menganalisis gejala serta masalah sosial dimasyarakat dengan meninjau dari berbagai aspek kehidupan atau suatu perpaduan yang ada dimasyarakat. Di dalam peningkatan mutu pendidikan pada masa sekarang ini, perlu diiringi proses belajar mengajar. Winkel (1991:36) menyatakan bahwa "belajar adalah suatu aktivitas mental/psikis yang berlangsung dalam interaksi aktif dengan lingkungan, yang menghasilkan perubahan dalam pengetahuan, pemahaman, keterampilan, dan sikap". Sementara itu Barlow (1985:88) berpendapat bahwa "belajar adalah suatu proses adaptasi dan penyesuaian tingkah laku yang berlangsung secara progresif". Selanjutnya Hamalik (2010:27) menjelaskan bahwa "belajar adalah modifikasi atau memperteguh kelakuan melalui pengalaman". Menurut pengertian ini, belajar merupakan suatu proses, suatu kegiatan dan bukan suatu hasil atau tujuan. Belajar bukan hanya mengingat, akan tetapi lebih luas dari itu, yakni pengalaman. Di dalam proses belajar mengajar harus memiliki metode agar siswa dapat belajar secara efektif dan efisien serta mengenai tujuan yang diharapkan.

Salah satu langkah untuk strategi itu ialah harus menguasai tehnik-tehnik pengajaran atau biasanya disebut metode pengajaran. Metode pembelajaran adalah cara yang digunakan untuk memecahkan suatu masalah yang dihadapi ataupun untuk menjawab suatu pertanyaan. Jadi metode pembelajaran merupakan cara-cara yang digunakan untuk mengimplementasikan rencana yang sudah disusun dalam kegiatan nyata agar tujuan yang telah disusun tercapai secara optimal. Menurut Suprayektif (2003:10) menyatakan bahwa Hasil belajar merupakan faktor yang penting dalam pelaksanaan pendidikan, karena hasil belajar merupakan tolak ukur keberhasilan pendidikan. Hasil belajar yang baik tergantung pada pelaksanaan interaksi belajar mengajar yang sesuai dengan perencanaan pembelajaran. Pelaksanaan interaksi belajar mengajar dipengaruhi oleh empat faktor. Keempat faktor tersebut adalah guru, siswa, kurikulum, dan faktor lingkungan.

Hamalik (2010: 30) menyatakan bahwa "hasil belajar akan terjadi pada perubahan tingkah laku seseorang. Misalnya dari tidak tahu menjadi tahu dan dari tidak mengerti menjadi mengerti". Sementara Sudjana (2009: 22) menyatakan bahwa "hasil belajar adalah suatu hasil yang diperoleh sebagai akibat dari proses belajar yang dilakukan oleh siswa, harus semakin tinggi hasil belajar yang diperoleh siswa, karena proses belajar merupakan sarana penunjang dari hasil belajar yang diperoleh siswa atau yang dicapainya". Dari beberapa pendapat para ahli di atas, dapat disimpulkan bahwa hasil belajar adalah suatu kemampuan yang dimiliki siswa setelah siswa tersebut menerima pengalaman belajarnya. 
Hasil belajar ini mempunyai peranan penting dalam proses pembelajaran, proses penilaian terhadap hasil belajar dapat memberikan informasi kepada guru tentang kemajuan siswa dalam upaya mencapai tujuantujuan belajarnya melalui kegiatan belajar yang dilakukan, selanjutnya dari informasi tersebut seorang guru dapat menyusun dan membina kegiatankegiatan siswa lebih lanjut baik untuk keseluruhan kelas maupun individu.

Melalui observasi yang dilakukan peneliti di kelas V SD Negeri 060924 Medan Amplas dijumpai sebagian besar siswa tidak suka dengan mata pelajaran IPS sehingga sebagian nilai yang diperoleh kurang memuaskan. Pemahaman siswa pada pokok bahasan sumber daya alam dan kegiatan ekonomi masyarakat masih sangat rendah. Hal ini dapat dilihat dari hasil ulangan harian yang didapat tidak sesuai dengan standar ketuntasan belajar siswa yaitu belajar dikatakan tuntas apabila siswa secara keseluruhan mampu mendapatkan nilai rata-rata 65 . Dari 30 orang siswa nilai terendah yang diperoleh adalah 40 sedangkan nilai tertinggi 60, hal ini dapat dikatakan bahwa nilai harian siswa belum mencapai standar ketuntasan belajar. Hal ini dikarenakan guru cenderung menggunakan metode ceramah dan bertanya kepada siswa dan siswa hanya mendengarkan penjelasan dari guru sehingga siswa menemukan kesulitan untuk mengarti dan memahami pelajaran tersebut. Pada saat guru menerangkan siswa mencari kesibukan sendiri di kelas. Guru mengajar menggunakan metode ceramah dan monoton tanpa disertai dengan penggunaan media, sehingga hal ini mengakibatkan siswa cenderung pasif terhadap materi yang diterangkan. Kepasifan siswa dalam belajar merupakan pertanda kurang baik di dalam proses pembelajaran, juga dalam perkembangan intelektual siswa. Siswa menjadi malas belajar, berfikir, dan malas berkompetisi saat belajar. Sehingga akan mengakibatkan terciptanya siswa yang tidak terampil serta tidak berintelektual, bahkan tidak menutup kemungkinan siswa akan merasa bahwa pelajaran IPS khususnya pokok bahasan sumber daya alam dan kegiatan ekonomi masyarakat sama sekali tidak penting dan tidak perlu untuk dipelajari.

Pembelajaran kooperatif tipe Team games Tournament (TGT) adalah satu model pembelajaran kooperatif yang mudah diterapkan, melibatkan aktivitas seluruh siswa tanpa harus ada perbedaan status, melibatkan siswa sebagai tutor sebaya dan mengandung unsur permainan dan reinforcement. Aktifitas belajar dengan permainan yang dirancang dalam pembelajaran kooperatif tipe TGT memungkinkan siswa dapat belajar lebih rileks disamping menumbuhkan tanggung jawab, kerjasama, persaingan sehat, dan keterlibatan belajar. Langkah-langkah pembelajaran kooperatif tipe TGT ini adalah pemberian materi pembelajaran, belajar kelompok, permainan dan pertandingan akademik, dan penghargaan kelompok.

Pada saat belajar kooperatif, siswa dibentuk dalam kelompok-kelompok yang terdiri dari 4 atau 5 orang untuk bekerja sama dalam menguasai materi yang diberikan guru (Slavin, 1995). Artzt \& Newman (1990:448) menyatakan 
bahwa dalam belajar kooperatif siswa belajar bersama sebagai suatu tim dalam menyelesaikan tugas-tugas kelompok untuk mencapai tujuan bersama. Salah satu tipe pembelajaran kooperatif adalah Team Games Tournament (TGT). Pembelajaran kooperatf tipe TGT adalah satu model pembelajaran kooperatif yang mudah diterapkan, melibatkan aktivitas seluruh siswa tanpa harus ada perbedaan status, melibatkan siswa sebagai tutor sebaya dan mengandung unsur permainan dan reinforcement.

Menurut Slavin (2008) langkah-langkah pembelajaran kooperatif tipe TGT mengikuti beberapa tahapan dari aktivitas pembelajaran kooperatif tipe TGT antara lain: pemberian materi pembelajaran, belajar kelompok, permainan dan pertandingan akademik, dan penghargaan kelompok. Untuk itu disusun langkah-langkah aktivitas belajar untuk mempermudah penelitian ini, diantaranya adalah sebagai berikut:

\section{Penyajian Kelas}

Pada langkah awal guru menyampaikan materi dalam penyajian kelas, biasanya dilakukan dengan pengajaran langsung atau dengan ceramah, diskusi yang dipimpin guru. Pada saat penyajian kelas ini siswa harus benar-benar memperhatikan dan memahami materi yang disampaikan guru, karena akan membantu siswa bekerja lebih baik pada saat kerja kelompok dan pada saat game karena skor game akan menentukan skor kelompok.

\section{Kelompok (Team)}

Kelompok biasanya terdiri dari 4 sampai 5 orang siswa yang siswanya heterogen dilihat dari prestasi akademik, jenis kelamin dan ras atau etnik. Fungsi kelompok adalah untuk lebih mendalami materi bersama teman kelompoknya dan lebih khusus untuk mempersiapkan angota kelompok untuk bekerja dengan baik dan optimal pada saat game. Adapun petunjuk penetapan anggota kelompok adalah sebagai berikut:

a. Membuat peringkat siswa

Kemampuan awal siswa diperoleh dari hasil ulangan siswa sebelumnya atau dari hasil ujian semester pada mata pelajaran IPS. Siswa diurutkan dengan membuat peringkat mulai dari siswa yang mempunyai kemampuan akademik tinggi, sedang dan rendah.

b. Menentukan banyak kelompok

Setiap angota kelompok kooperatif beranggotakan 5-6 orang siswa. Dalam menentukan banyak kelompok perlu diperhatikan banyak anggota tiap kelompok dan banyak siswa tiap kelas.

c. Penyusunan anggota kelompok

Penyusunan anggota kelompok berdasarkan daftar siswa yang sudah dibuat peringkat, yang diupayakan setiap kelompok belajar siswa terdiri dari kemampuan akademik tinggi, sedang dan rendah sehingga antara kelompok satu dengan kelompok lain rata-rata berkemampuan seimbang.

\section{Game}


Game terdiri dari pertanyaan-pertanyaan yang dirancang untuk menguji pengetahuan yang didapat siswa dari penyajian kelas dan belajar kelompok. Kebanyakan game terdiri dari pertanyaan-pertanyaan yang bernomor. Siswa memilih kartu yang bernomor dan mencoba menjawab pertanyaan yang sesuai dengan nomor itu. Siswa yang menjawab benar pertanyaan itu mendapat skor. Skor ini yang nantinya dikumpulkan siswa untuk turnamen mingguan.

\section{Turnamen}

Turnamen biasanya dilakukan pada akhir minggu atau pada setiap unit setelah guru melakukan persentasi kelas dan kelompok sudah mengerjakan lembar kerja. Turnamen pertama guru membagi siswa kedalam beberapa turnamen. Tiga siswa tertinggi dikelompokkan pada meja I, tiga siswa selanjutnya pada meja II dan yang seterusnya yang dapat dilihat di bagan 1.

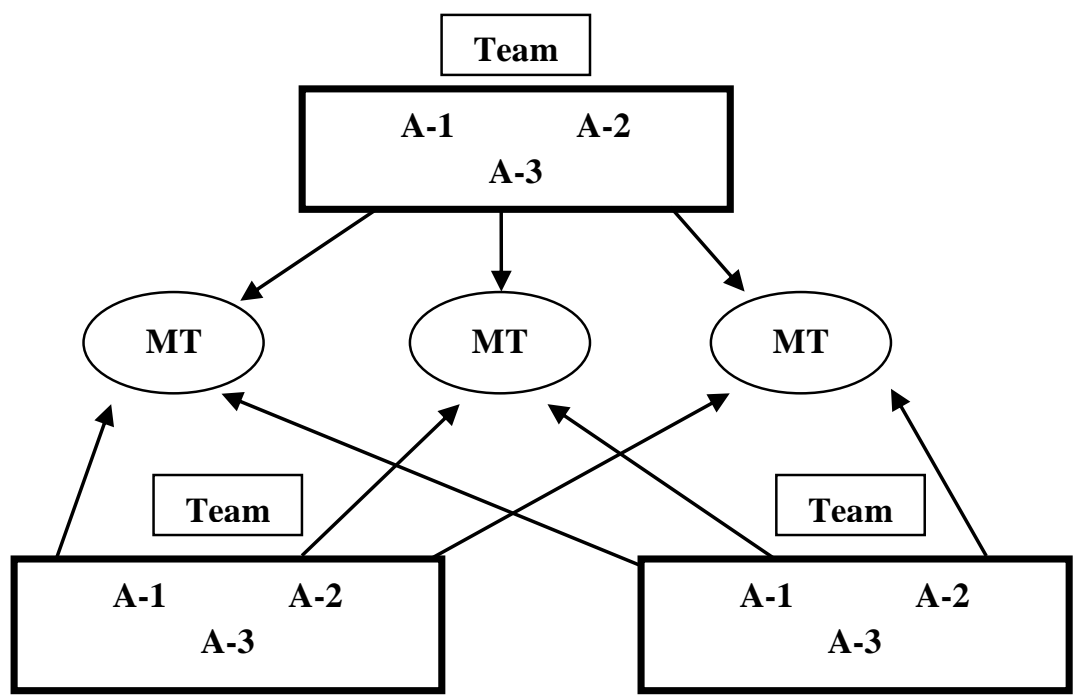

Gambar 1. Bagan Penempatan siswa dalam kelompok pada meja pertandingan. Meja turnament 1 (MT 1) diisi oleh wakil-wakil kelompok dengan kemampuan awal yang tinggi, kemudian diikuti dengan meja turnamen 2 (MT 2) dan meja turnamen 3 (MT 3) yang tingkat akademinya lebih rendah. (Sumber: Slavin, 2008).

\section{Team Recognize (Penghargaan Kelompok)}

Guru kemudian mengumumkan kelompok yang menang, masingmasing team akan mendapat sertifikat atau hadiah apabila rata-rata skor memenuhi kriteria yang ditentukan. Penghargaan yang diberikan berdasarkan nilai dari masing-masing team kelompok tersebut ialah: team mendapat julukan "Super Team" jika rata-rata skor 50 atau lebih, "Great Team" apabila rata-rata mencapai 45-50 dan "Good Team" apabila rata-ratanya 40-45. Kriteria penghargaan kelompok yang ditetapkan slavin (2008) seperti tabel dibawah ini:

Tabel 1. Penghargaan Kelompok

\begin{tabular}{|c|c|}
\hline Kriteria & Penghargaan \\
\hline Nilai $\geq 50$ & Kelompok Super \\
\hline $45 \leq$ nilai $<50$ & Kelompok Terbaik \\
\hline
\end{tabular}




\begin{tabular}{|c|c|}
\hline $40 \leq$ nilai $<45$ & Kelompok Baik \\
\hline Nilai $\leq 40$ & Kelompok Cukup \\
\hline
\end{tabular}

Aktifitas belajar dengan permainan yang dirancang dalam pembelajaran kooperatif tipe TGT memungkinkan siswa dapat belajar lebih rileks disamping menumbuhkan tanggung jawab, kerjasama, persaingan sehat, dan keterlibatan belajar. Langkah-langkah pembelajaran kooperatif tipe TGT ini adalah pemberian materi pembelajaran, belajar kelompok, permainan dan pertandingan akademik, dan penghargaan kelompok.

\section{METODE}

Jenis penelitian yang dilakukan dalam penelitian ini adalah Penelitian Tindakan Kelas (PTK) yaitu suatu model penelitian yang dikembangkan di kelas sesuai dengan kebutuhan atau permasalahan yang terjadi di dalam kelas tersebut. Sesuai dengan jenis penelitian ini, maka penelitian ini memiliki tahaptahap penelitian berupa siklus. Penelitian ini dilakukan dalam dua siklus yang didalamnya terdapat empat tahapan utama, yaitu perencanaan, tindakan, pengamatan, dan refleksi seperti yang telah digambarkan oleh Arikunto dkk (2006: 16) pada bagan sebagai berikut:

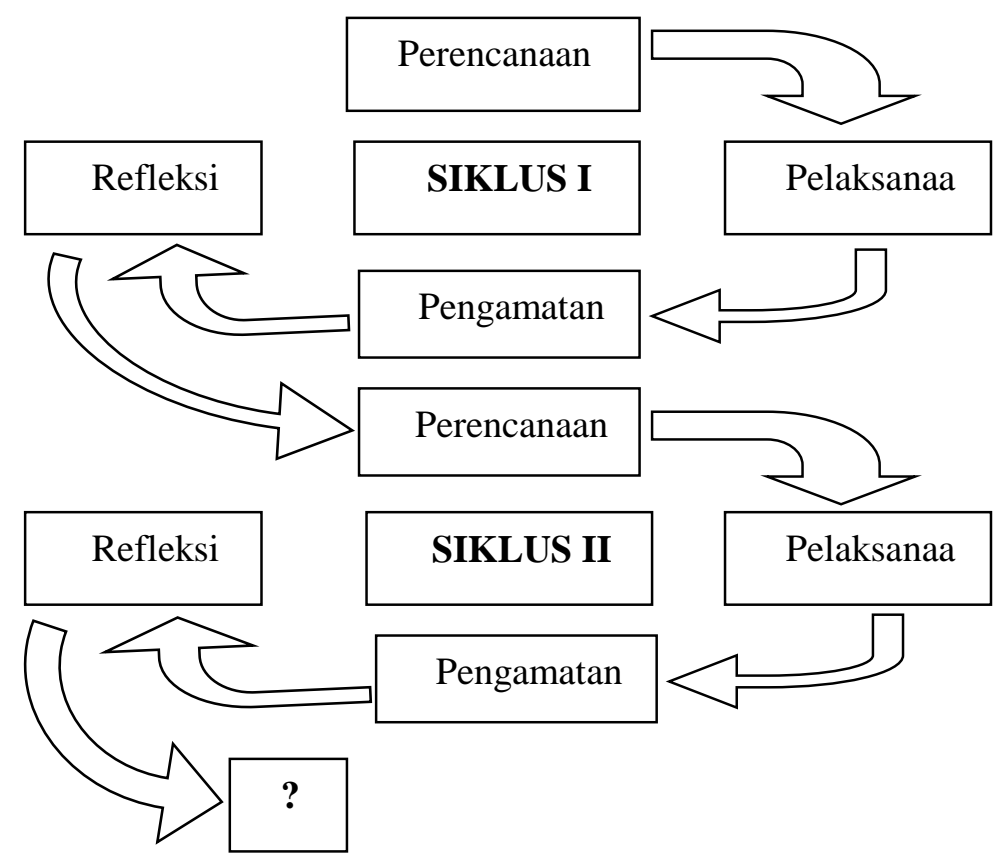

Gambar 2. Skema PTK menurut Arikunto, dkk (2006:16)

Untuk mengetahui keefektifan suatu metode dalam kegiatan pembelajaran, perlu dilakukan analisis data. Pada penelitian tindakan kelas ini, digunakan analisis deskripsi kualitatif, yaitu suatu metode penelitian yang bersifat menggambarkan kenyataan atau fakta yang sesuai dengan data yang diperoleh dengan tujuan untuk mengetahui respon siswa terhadap kegiatan pembelajaran serta aktivitas siswa selama proses pembelajaran berlangsung. Untuk analisis tingkat keberhasilan atau persentase tingkat ketuntasan belajar 
siswa setelah proses belajar mengajar berlangsung pada tiap siklusnya, dilakukan dengan cara memberikan evaluasi berupa soal tes tertulis pada setiap akhir siklus.

\section{Penilaian Hasil Belajar}

Untuk menentukan hasil belajar siswa digunakan rumus (Sudjana, 2009:54):

$$
S k=B-\frac{S}{O-1}
$$

Keteranga:

$$
\begin{aligned}
& \text { Sk : Skor yang diperoleh } \\
& \text { B : Jawaban yang benar } \\
& \text { S : Jawaban yang salah } \\
& \text { O : Kemungkinan jawaban atau option }
\end{aligned}
$$

\section{Penilaian Tes}

Dalam penilaian ini peneliti menjumlahkan nilai yang diperoleh siswa, selanjutnya, dibagi dengan jumlah siswa kelas tersebut sehingga diperoleh nilai rata-rata. Nilai rata-rata ini di dapat dengan menggunakan rumus (Aqib, 2010:204):

$$
\bar{X}=\frac{\sum X}{\sum N}
$$

Keterangan:

$\bar{X} \quad$ : Nilai rata-rata

$\Sigma \mathrm{X}:$ Jumlah semua nilai siswa

$\Sigma \mathrm{N}$ : Jumlah siswa

\section{Ketuntasan Klasikal}

Suatu kelas dikatakan sudah tuntas belajar jika kelas tersebut terdapat $80 \%$ yang telah tuntas belajar. Ketuntasan klasikal dihitung dengan menggunakan rumus (Aqib, 2010:205):

$$
P=\frac{\text { Jumlah Siswa yang Tuntas Belajar }}{\text { Jumlah Seluruh Siswa }} \times 100 \%
$$

\section{HASIL DAN PEMBAHASAN}

\section{Siklus I}

Perencanaan 
Pada tahap perencanaan ini, hal yang telah dipersiapkan pada siklus I ini adalah beberapa perangkat pembelajaran dan instrument penelitian. Adapun perangkat pembelajaran yang dihasilkan adalah Rencana Pelaksanaan Pembelajaran (RPP), bahan ajar, Lembar Observasi dan Lembar Evaluasi/Test. Langkah-langkah yang disusun dalam RPP dibuat sesuai dengan langkahlangkah pada metode pembelajaran Team Games Tournament. Bahan ajar merupakan kumpulan materi dari topik yang akan dibahas. Sedangkan instrument yang dihasilkan adalah lembar observasi siswa yang berisi tentang keaktifan siswa dalam proses pembelajaran, kemudian lembar evaluasi yang berisi tentang kompetensi yang harus dikuasai oleh siswa.

\section{Tahap Pelaksanaan Tindakan}

Setelah tahap perencanaan disusun, maka tahap selanjutnya adalah melaksanakan rencana pembelajaran yang telah direncanakan dalam rencana pelaksanaan pembelajaran. Guru menjelaskan materi pelajaran pokok bahasan sumber daya alam dan kegiatan ekonomi masyarakat. Pada saat pelaksanaan tindakan ini, guru melaksanakan kegiatan belajar mengajar sesuai dengan RPP yang telah disusun terlebih dahulu sementara itu, siswa menyimak dan mendengarkan materi yang sedang dijelaskan oleh guru. Pada saat tindakan ini, guru menyuruh kepada setiap kelompok untuk mendiskusikan hal-hal yang belum dimengerti sebelum game dimulai. Guru mengawasi dan membimbing siswa yang sedang berdiskusi. Sebelum game dimulai, peneliti memberi arahan kepada siswa untuk melakukan game, pertanyaan game merupakan pertanyaan yang berhubungan dengan materi yang telah di ajarkan yaitu pokok bahasan sumber daya alam dan kegiatan ekonomi masyarakat. Selanjutnya guru memberikan skor kepada kelompok yang dapat menjawab pertanyaan yang telah dipilihnya kemudian peneliti mengumumkan kepada siswa hasil dari permainan. Guru membagikan soal-soal postes siklus I kepada siswa. Setelah membagikan soal, peneliti memberi arahan kepada siswa cara menjawab soal tersebut dan peneliti mengingatkan siswa agar mencantumkan nama dan kelas. Kemudian siswa mengerjakan soal postes dengan seksama.

\section{Pengamatan}

Pada tahap ini observer langsung mengamati aktivitas peneliti dengan menggunakan butir lembar obsevasi. Pengamat melaporkan apa yang dilakukan peneliti selama pembelajaran berlangsung. Adapun hasil observasi yang dilakukan observer dapat dilihat pada tebel di bawah ini.

Tabel 2. Data Observasi Guru pada Siklus I

\begin{tabular}{|c|l|c|c|c|c|}
\hline No & Kegiatan & $\mathbf{1}$ & $\mathbf{2}$ & $\mathbf{3}$ & $\mathbf{4}$ \\
\hline 1 & Membuka pelajaran & & & & \\
\hline
\end{tabular}

8 MUKADIMAH: Jurnal Pendidikan, Sejarah, dan Ilmu-ilmu Sosial, 2(2), 2018 


\begin{tabular}{|c|l|r|r|r|l|}
\hline 2 & Menjelaskan materi pembelajaran & $\checkmark$ & & \\
\hline 3 & Memberikan motivasi kepada siswa & $\checkmark$ & & & \\
\hline 4 & $\begin{array}{l}\text { Penggunaan metode pembelajaran Team Games } \\
\text { Tournament (TGT) dalam penyampaian materi } \\
\text { pembelajaran }\end{array}$ & $\checkmark$ & & & \\
\hline 5 & Penggunaan waktu dalam pembelajaran & & & $\checkmark$ & \\
\hline 6 & Penguasaan materi pembelajaran & & & & \\
\hline 7 & Melibatkan siswa dalam pembelajaran & & & & \\
\hline 8 & Penguasaan kelas & $\checkmark$ & & \\
\hline 9 & Interaksi dengan siswa & & & & \\
\hline 10 & Pengelolahan kelas & $\checkmark$ & & \\
\hline 11 & Menutup pembelajaran & & & $\checkmark$ & \\
\hline & Jumlah $\frac{19}{44} \times 100=43,18$ & & & \\
\hline
\end{tabular}

Keterangan: $1=$ kurang $\quad 2$ = cukup $\quad 3$ = baik $\quad 4$ = sangat baik

Pada tabel di atas maka dapat dilihat bahwa kemampuan guru selama pembelajaran dengan menggunakan Team Games Tournament mengalami peningkatan yaitu mencapai nilai rata-rata 90,90. Berdasarkan hasil observasi ini, maka guru tidak perlu melakukan perbaikan pembelajaran pada siklus selanjutnya.

\section{Refleksi}

Dari hasil analisis yang dilakukan dapat disimpulkan bahwa dari hasil pengamatan dalam tindakan siklus II lebih baik dari siklus I. Hal ini dapat dilihat dari proses pembelajaran, dimana siswa sudah memahami materi yang diajarkan yaitu pokok bahasan sumber daya alam dan kegiatan ekonomi masyarakat sehingga hasil belajar siswa pun mengalami peningkatan. Berdasarkan hasil perolehan siklus I, maka dapat disimpulkan bahwa kemampuan siswa dalam memahami materi pelajaran meningkat. Hal ini dapat dilihat dari meningkatnya perolehan nilai siswa dimana nilai rata-rata mencapai 7,25. Dari 30 siswa terdapat 23 siswa atau 76,67\% telah mencapai ketuntasan dan hanya 7 orang siswa atau 23,33\% yang belum mencapai ketuntasan. Dengan demikian, pada siklus II ini hasil belajar siswa telah mencapai ketuntasan, sehingga tidak perlu lagi melakukan tindakan pembelajaran kesiklus berikutnya.

\section{PENUTUP}

Berdasarkan analisis data yang telah dilakukan peneliti dalam penelitian ini, maka dapat ditarik kesimpulan sebagai berikut:

1. Penggunaan metode pembelajaran Team Games Tournament (TGT) pada mata pelajaran IPS pokok bahasan sumber daya alam dan kegiatan ekonomi masyarakat dapat meningkatkan hasil belajar siswa.

2. Penggunaan metode pembelajaran Team Games Tournament (TGT) pada pembelajaran IPS dapat mempermudah siswa dalam memahami konsep 
dalam pelajaran IPS khususnya pokok bahasan sumber daya alam dan kegiatan ekonomi masyarakat.

3. Berdasarkan hasil Pre-Tes yang dilakukan peneliti nilai rata-rata yang diperoleh siswa adalah 4,40 dan siswa yang tuntas sebanyak 4 siswa atau $13,33 \%$.

4. Dari pelaksanaan siklus I nilai rata-rata yang diperoleh siswa adalah 5,47 dan siswa yang tuntas adalah sebanyak 10 siswa atau 33,33\%.

5. Hasil pelaksanaan siklus II nilai rata-rata yang diperoleh siswa adalah 7,25 dan jumlah siswa yang tuntas sebanyak 23 siswa atau 76,67\%.

\section{REFERENSI}

Adisukarjo, S, dkk. (2004). Horizon Pengetahuan Sosial. Jakarta: Yudhistira.

Aqib, Diniati, Khotimah. (2009). Penelitian Tindakan Kelas. Bandung: Yrama Widya.

Arikunto, S. (2006). Penelitian Tindakan Kelas. Jakarta: Bumi Aksara.

Arsyad, A. (2007). Media Pembelajaran. Jakarta: Raja Grafindo Persada.

Dimyati, M. (1999). Belajar dan Pembelajaran. Jakarta: Rineka Cipta.

Hamalik, O. (2010). Proses Belajar Mengajar. Jakarta: Bumi Aksara.

Lie, A. (2002). Cooperative Learning. Jakarta: Grassindo.

Sardiman. (2009). Interaksi Dan Motivasi Belajar Mengajar. Jakarta: Raja Grafindo.

Slameto. (2003). Belajar dan Faktor-Faktor yang Mempengaruhinya. Jakarta: Rineka Cipta.

Sudjana, N. (2009). Penilaian Hasil Proses Belajar Mengajar. Bandung: Remaja Rosdakarya.

Syah, M. (2010). Psikologi Pendidikan dengan Pendekatan Baru. Bandung: Remaja Rosdakarya.

Trianto. (2010). Mendesain Model Pembelajaran Inovatif-Progresif. Jakarta: Kencana Prenada Media Group. 